\title{
Acute toxicity of sodium metabisulphite on mangrove crab Ucides cordatus (Decapoda, Ucididae)
}

\author{
ADRIANA B. PEDALE ${ }^{1}$, RODRIGO Y. FUJIMOTO ${ }^{2}$, RUDÃ F.B. SANTOS ${ }^{3}$ and FERNANDO A. ABRUNHOSA ${ }^{1}$ \\ ${ }^{1}$ Laboratório de Carcinologia, Universidade Federal do Pará, Alameda Leandro Ribeiro, s/n, 68600-000 Bragança, PA, Brasil \\ ${ }^{2}$ Embrapa Tabuleiros Costeiros, Av. Beira Mar, 3250, 49025-040 Aracaju, SE, Brasil \\ ${ }^{3}$ Laboratório de Ictioparasitologia e Piscicultura, Universidade Federal do Pará, \\ Alameda Leandro Ribeiro, s/n, 68600-000 Bragança, PA, Brasil
}

Manuscript received on June 20, 2011; accepted for publication on October 10, 2011

\begin{abstract}
The sodium metabisulphite salt is usually used in shrimp culture to prevent black spot. Unfortunately the toxicological effect of this xenobiotic in decapod crabs is unknown. Thus, the present study aims to investigate the sodium metabisulphite $\mathrm{LC}_{50}-96 \mathrm{~h}$ in the mangrove species Ucides cordatus. Crabs were collected in the tidal creek margins in Bragança estuarine and were submitted to preliminary test (screening) and posterior definitive test. Crabs were exposed in five different concentrations and a control group in five replicates, two crabs per recipient (5 L) during 96 hours. A negative correlation was observed to sodium metabisulphite concentration in relation to dissolved oxygen and $\mathrm{pH}$. At the end of the experiment were obtained the following mortality index in relation to sodium metabisulphite concentrations: $100 \%$ in $86.0 \mathrm{mg} . \mathrm{L}^{-1}, 74 \%$ in $62.0 \mathrm{mg} . \mathrm{L}^{-1}, 52 \%$ in $52.0 \mathrm{mg} . \mathrm{L}^{-1}, 44 \%$ in $38.0 \mathrm{mg} . \mathrm{L}^{-1}$. The value of $\mathrm{LC}_{50}-96 \mathrm{~h}$ for $U$. cordatus was determinate at $42.58 \mathrm{mg} . \mathrm{L}^{-1} / \mathrm{Na}_{2} \mathrm{~S}_{2} \mathrm{O}_{5}$. The results strongly indicate that sodium metabisulphite is toxic for $U$. cordatus, and this crab could be used for biomonitoring the environmental impact.
\end{abstract}

Key words: shrimp culture, environmental impact, metabisulphite, lethal concentration, neotropical species.

\section{INTRODUCTION}

The production of aquatic organisms in captivity has increased significantly worldwide. Since 1990 the commercial aquaculture expanded in Brazil with the marine shrimp farming due to production development at industrial level for the species Litopennaeus vanamei (Boone 1931) (Ostrensky et al. 2008).

However, like other animal husbandry activities, the aquaculture needs inputs to its production and

Correspondence to: Fernando Araujo Abrunhosa

E-mail: faraujo@ufpa.br generates high amounts of waste, causing environmental impact (Vinatea 1999). Among these wastes generated by shrimp production is the sodium metabisulphite that is commonly used in the process of shrimp capture aiming to avoid the melanosis appearance. But this agent reduces the concentration of dissolved oxygen and alters the water $\mathrm{pH}$ causing mortality of aquatic biota (Silva 1988, Macintosh and Phillips 1992, Miri and Chouikhi 2005).

The proper amount of sodium metabisulphite that could be safely released into the environment 
is unknown. As result from shrimp farming, large quantities of chemicals are released in the estuarine waters (Aragão et al. 2008).

To evaluate the impacts of these xenobiotics on aquatic organisms into the ecosystem, toxicity tests have been performed (Lombardi 2004). The acute toxicity test provides quick answer estimating the lethal effects of a particular toxicant on aquatic organisms, upon exposure to different concentrations of a chemical agent by determining the deleterious action on the organisms tested.

Organisms present in regions exposed to xenobiotic should be preferably used to toxicity tests (Rand and Petrocelli 1985). Shrimp farms have been found responsible for effluent discharge on the estuaries and mangroves. With that in mind, this work target a species, the Ucides cordatus (Linnaeus, 1763), which has high economic importance as an exploited organism by coastal communities at the margins of mangrove (Nascimento 1993, Glaser 1999, Glaser and Diele 2004, Diele et al. 2005).

The aim of this study is to determine the acute toxicity (LC50 - 96h) of xenobiotic sodium metabisulphite (Na2S2O5) for adult crab $U$. cordatus, and to evaluate its sensitivity to sodium metabisulphite.

\section{MATERIALS AND METHODS}

The tests to evaluate the toxicity of sodium metabisulphite were performed at the Laboratory of Carcinology, Universidade Federal do Pará Bragança - PA, Brazil. Crabs were collected in August 2009 manually on Furo Grande estuarine channel ( $\left.0^{\circ} 50^{\prime} 42^{\prime \prime} \mathrm{S} / 46^{\circ} 39^{\prime} 00^{\prime \prime} \mathrm{W}\right)$, inserted in the Marine Conservation Unit RESEX Caeté-Taperaçu.

After capture, crabs were placed in plastic buckets and conducted to the laboratory, washed and maintained in polyethylene tanks of $500 \mathrm{~L}$. Marine water was used for acclimation period and bioassays (collected $35 \mathrm{~km}$ from the coast of the peninsula Bragança, in northeastern Pará).
The water was mechanically filtered by suction pump with filter of compresse teflon in order to avoid possible transit of planktonic organisms. The water was stored in polyethylene containers and kept under constant aeration and biological filtration. The water was diluted with distilled water to obtain 15 ppt salinity.

During this period, crabs were placed in polyethylene tanks, the photoperiod was natural and the food daily offered constituted of senescent leaves of Rizophora mangle. Feeding was suspended 24 hours before application of toxicological tests.

Preliminary tests were carried out to determine the lowest concentration of xenobiotic sodium metabisulphite with $100 \%$ mortality ("screening"). After screening, sensitivity tests were performed with potassium chloride $(\mathrm{KCl})$ as reference substance in six concentrations $(0.0,125,250,500$ and $\left.650 \mathrm{mg} . \mathrm{L}^{-1}\right)$ with two replicates.

To conduct the definitive test a randomized design was used with six concentrations of sodium metabisulphite $(0.0,20.0,38.0,52.0,62.0,86.0$ $\mathrm{mg} . \mathrm{L}^{-1}$ ) and five replicates. Experimental trial was conducted in containers with $5 \mathrm{~L}$ capacity, constant artificial aeration and stocking density of 2 crabs per container weighing $20.49 \mathrm{~g} \pm 2.1$ in a semi static system for 96 hours.

Mortality rate was monitored every 24 hours for 96 hours. Dead crabs were removed with the aid of sieves to maintain the water quality. The water parameters such as dissolved oxygen, temperature, $\mathrm{pH}$, total ammonia and salinity were measured every 12 hours.

To determine the $\mathrm{LC}_{50^{-}}-96 \mathrm{~h}$, the mortality data were analyzed with the statistical program Trimmed Spearman Karber (Hamilton et al. 1977). The method for the tests was according to IBAMA (1987) with data plotting in graphs of linear regression was performed with the Excel 2007, to correlate the dissolved oxygen and $\mathrm{pH}$ with metabisulphite concentrations. 


\section{RESULTS}

During the test for acute toxicity with sodium metabisulphite, the salinity (15ppt) and temperature $\left(26^{\circ} \mathrm{C} \pm 1\right)$ did not affect the maintenance of crabs in the experimental condition and remained within the range recommended by IBAMA (1987).

Dissolved oxygen values ranged from $7.3 \mathrm{mg} . \mathrm{L}^{-1}$ (0.0 mg.L $\mathrm{L}^{-1}$ of $\left.\mathrm{Na}_{2} \mathrm{~S}_{2} \mathrm{O}_{5}\right)$ and $2.0 \mathrm{mg} . \mathrm{L}^{-1}\left(86.0 \mathrm{mg} . \mathrm{L}^{-1}\right.$ of $\left.\mathrm{Na}_{2} \mathrm{~S}_{2} \mathrm{O}_{5}\right)$ and $\mathrm{pH}$ values ranged from $8.4(0.0$ mg. $\mathrm{L}^{-1}$ of $\left.\mathrm{Na}_{2} \mathrm{~S}_{2} \mathrm{O}_{5}\right)$ and $4.7 \mathrm{mg} . \mathrm{L}^{-1}\left(86.0 \mathrm{mg} . \mathrm{L}^{-1}\right.$ of $\mathrm{Na}_{2} \mathrm{~S}_{2} \mathrm{O}_{5}$ ) (Figure 1).
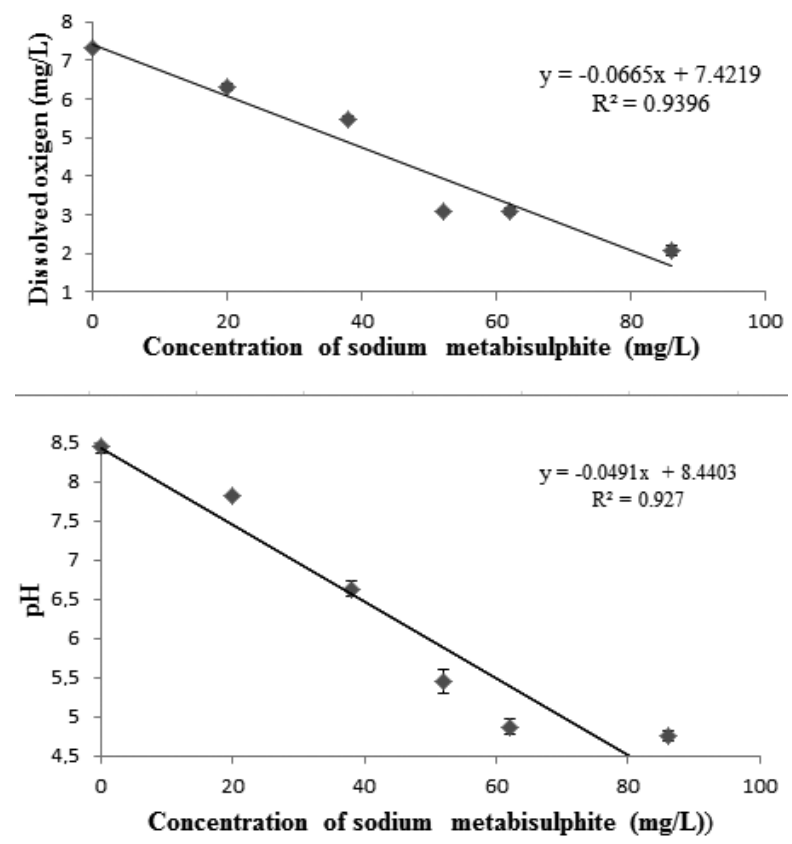

Figure 1 - Correlation between dissolved oxygen and $\mathrm{pH}$ over the concentration of sodium metabisulphite in acute toxicity test in Ucides cordatus.

Increased mortality was observed due to an increment in the metabisulphite concentration. Moreover, data of dissolved oxygen $(\mathrm{y}=-0.0642 \mathrm{x}$ $\left.+7.4879, \mathrm{R}^{2}=0.9769\right)$ and $\mathrm{pH}(\mathrm{y}=-0.0494+$ $8.4059 \mathrm{x}$ ) were correlated with mortality rates in the $U$. cordatus, and a secondary effect of metabisulphite was observed on water quality that affected indirectly the survival of crabs (Figure 1).

Regarding to potassium chloride $(\mathrm{KCl}) \mathrm{LC}_{50}$ (I) - 96 hours at $652 \mathrm{mg} . \mathrm{L}^{-1}$ was found. Lower limit was $545 \mathrm{mg} . \mathrm{L}^{-1}$ and the highest $761 \mathrm{mg} . \mathrm{L}^{-1}$. The acute toxicity test to sodium metabisulphite had the LC (I) 50 - 96 hours was $42.58 \mathrm{mgL}^{-1}$ with lower limit $35.64 \mathrm{mg} . \mathrm{L}^{-1}$ and the highest $50.89 \mathrm{mg} . \mathrm{L}^{-1}$.

\section{DISCUSSION}

Sodium metabisulphite is a potent antioxidant (Laurila et al. 1998). This study showed the reduction of dissolved oxygen at all concentrations test.

According to Aragão et al. (2008), the scientific literature lacks information about the minimum amount of this compound that can be released into the environment without harming the ecosystem. The fact that xenobiotic decrease dissolved oxygen from water already could be classified as toxic and harmful to the environment.

The correlation between dissolved oxygen and mortality showed increased mortality as dissolved oxygen level decrease (Figure 2). Dissolved oxygen is the most critical indicator of water quality in controlling the growth and survival of organisms (Boyd 1989). The regression analysis determined the minimum concentration of sodium metabisulphite that does not cause death in crabs. Therefore, the sodium metabisulphite discharge in the water bodies of the shrimp farms should not be released with concentrations of sodium metabisulphite higher than $38.0 \mathrm{mg} . \mathrm{L}^{-1}$ (38.75 mg. $\mathrm{L}^{-1}$ according to regression). At this concentration the dissolved oxygen levels are below the minimum allowed to brackish water (equal or greater than $5 \mathrm{mg} . \mathrm{L}^{-1}$ ) under Brazilian resolution CONAMA 020/1986.

Following the same resolution the values of $\mathrm{pH}$ must be between 6.5 to 8.5 , but in the concentration of $52.0 \mathrm{mgL}^{-1}\left(\mathrm{Na}_{2} \mathrm{~S}_{2} \mathrm{O}_{5}\right)$ the $\mathrm{pH}$ reached $4.0 \mathrm{mg} . \mathrm{L}^{-1}$, value lower than permitted by the law, indicating a negative effect of metabisulphite in estuary waters. This occurs due to an increase in the sodium metabisulphite and its correlated releasing of sodium sulphate acid resulting in water acidification. As higher the concentration of sodium metabisulphite, higher the potential for chemical reaction, causing a 

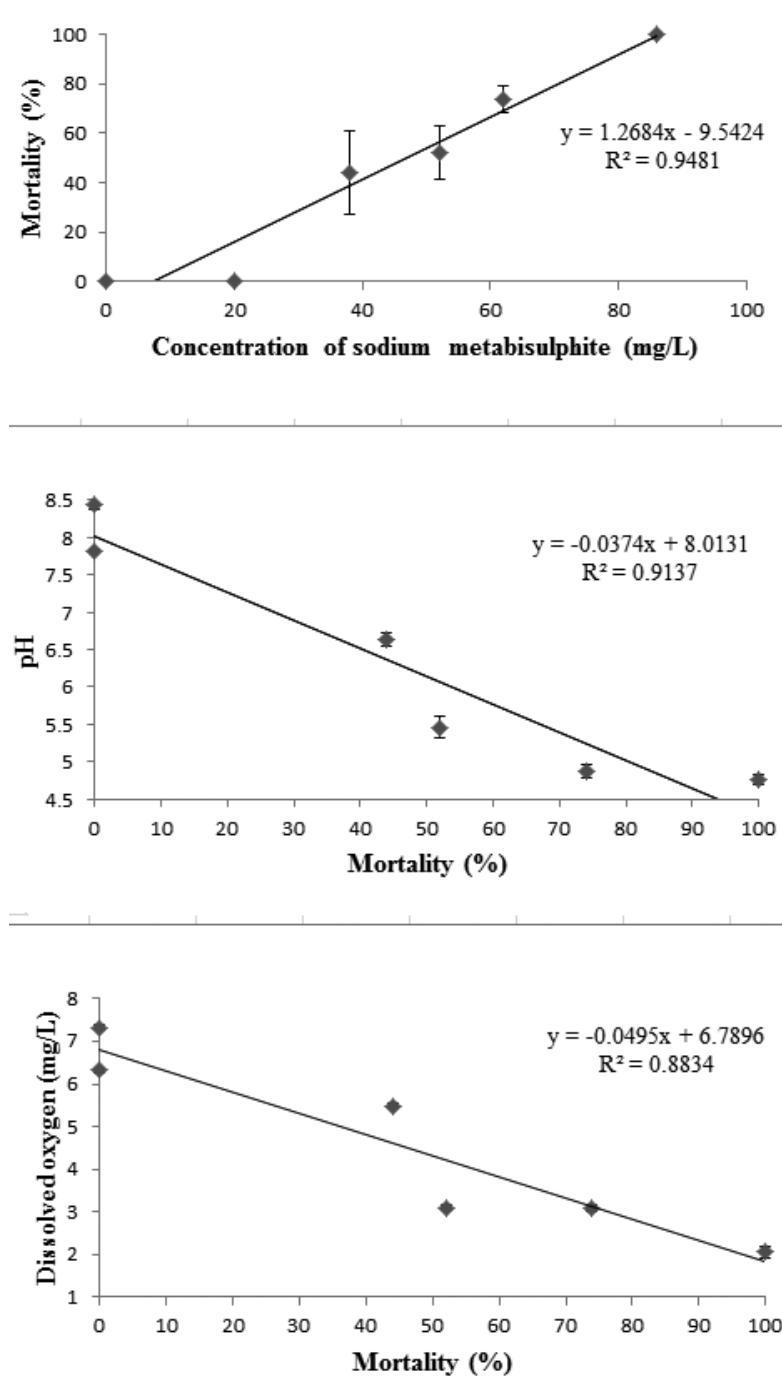

Figure 2 - Correlation concentration, $\mathrm{pH}$ and dissolved oxygen for mortality in acute toxicity test in Ucides cordatus.

decrease in $\mathrm{pH}$ values (Valença 2003). In addition to that, it has a synergistic effect increasing mortality rate of organisms exposed to this solution (BadaróPedroso et al. 2002, Aragão et al. 2008).

Considering the resolution CONAMA 020/1986, the shrimp farms that use this substance release metabisulphite in water bodies at concentrations lower than $38 \mathrm{mg} . \mathrm{L}^{-1}$. Oxygen levels and $\mathrm{pH}$ are within the acceptable range for estuaries and reduce the environmental impacts of this activity.

However, it is worth to note that a decrease in oxygen and $\mathrm{pH}$ contributes to increased mortality
(Figure 2). But, it is not the only responsible for mortality, since at a concentration of $34 \mathrm{mg} . \mathrm{L}^{-1}$ of sodium metabisulphite, the dissolved oxygen and $\mathrm{pH}$ - within the standards established by CONAMA $020 / 86$ presented a mortality of $44 \%$ \pm 16.73 . This work corroborated the finding of Aragão et al. (2008) that observed mortalities of Mysidopsis juniae even at concentrations where the oxygen level was in the acceptable limit in similar test conditions.

The acute toxicity to sodium metabisulphite had the LC $(\mathrm{I})_{50}$ - 96 hours estimated at $42.58 \mathrm{mgL}^{-1}$ with lower limit of $35.64 \mathrm{mg} . \mathrm{L}^{-1}$ and the upper 50.89 mg. $\mathrm{L}^{-1}$. Data provided by the Information Sheet for Chemical Safety (MSDS) of Fmaia (2010) reported acute toxicity data for cladoceran (Daphnia magna) with $\mathrm{LC}_{50}$ (48 hours) equal to 89 mg.L ${ }^{1}$. Aragão et al. (2008) determined the $\mathrm{LC}_{50}$ (96 hours) for Mysidopsis juniae at $38.2 \pm 4.7 \mathrm{mg} . \mathrm{L}^{-1}$. Galli et al. (2012) determined the $\mathrm{LC}_{50}$ (48 hours) for zoea I of the land crab Cardisoma guanhumi in $34 \pm 1.1 \mathrm{mg} / \mathrm{L}$, for megalopa $31.1 \pm 1.9 \mathrm{mg} / \mathrm{L}$, and for post-larvae $30.6 \pm 0.5 \mathrm{mg} / \mathrm{L}$.

In toxicity tests it is common to use organisms that are early in their life stage, due to increased sensitivity of these organisms. Anger (1995) reported for some species of crabs (Ucididae family) showed the highest resistance of $U$. cordatus (NG et al. 2008) to adverse factors in the benthic environment.

According to Santos (2002), U. cordatus may be an important biomonitor of critical areas, as well as being found in much of the Brazilian coast. This crab shows sensitivity to several pollutants. Besides, adults of $U$. cordatus were efficient in the use of acute toxicity tests, which can be used as bioindicators of estuarine ecosystem.

The tests with species' adults are more useful to be realized due its easy capture and acclimation. Another factor that can be announced is that the $U$. cordatus has commercial value in detriment of other species destined for human consumption. 
In conclusion, the effluent discarded by shrimp farms containing sodium metabisulphite at concentrations of $38 \mathrm{mg} . \mathrm{L}^{-1}$ causes dissolved oxygen levels below to the recommended by CONAMA Resolution 020/1986. Above $52 \mathrm{mgL}^{-1}$ the value of $\mathrm{pH}$ is also lower than that recommended by this same resolution.

The acute toxicity to sodium metabisulphite had the LC $(\mathrm{I})_{50}-96$ hours estimated at $42.58 \mathrm{mgL}^{-1}$ with lower limit of $35.64 \mathrm{mg} . \mathrm{L}^{-1}$ and the upper limit of $50.89 \mathrm{mg} . \mathrm{L}^{-1}$.

The adult crab $U$. cordatus can be used to indicate the discharge of sodium metabisulphite since its $\mathrm{LC}_{50}$ (96 hours) had the lower minimum near $\mathrm{LC}_{50}$ (96 hours) compared to other organisms, including younger forms of this species.

\section{ACKNOWLEDGMENTS}

We thank Orlando Bastião Surlo Galli for laboratory help and field collection, and the reviewers for valuable comments. This study was financed by the Coordenação de Aperfeiçoamento de Pessoal de Nível Superior (CAPES).

\section{RESUMO}

O metabissulfito de sódio é um sal habitualmente usado no cultivo de camarão a fim de se evitar a melanose. Infelizmente o efeito toxicológico deste xenobiótico em caranguejos decápodes é desconhecido. O presente estudo objetiva investigar o $\mathrm{LC}_{50}-96 \mathrm{~h}$ do metabissulfito de sódio na espécie Ucides cordatus em manguezal. A coleta dos caranguejos foi realizada nas margens do canal de maré estuarino em Bragança/PA. Os caranguejos foram submetidos a um teste preliminar (screening) e posteriormente ao teste definitivo, e foram expostos a cinco concentrações diferentes e um grupo controle com cinco repetições, com dois caranguejos por recipiente (5 L) durante 96 horas. Houve correlação negativa no aumento da concentração de metabissulfito de sódio com o oxigênio dissolvido e $\mathrm{pH}$. No final do experimento foram obtidos os seguintes níveis de índice de mortalidade em relação às concentrações de metabissulfito de sódio: $100 \%$ em $86,0 \mathrm{mg} . \mathrm{L}^{-1}, 74 \% \mathrm{em}$ 62,0 mg.L $\mathrm{L}^{-1}, 52 \%$ em 52,0 mg. $\mathrm{L}^{-1}, 44 \%$ em 38,0 mg.L $\mathrm{L}^{-1}$. $\mathrm{O}$ valor da $\mathrm{LC}_{50} 96 \mathrm{~h}$ para $U$. cordatus foi determinado em 42,58 mg.L $\mathrm{L}^{-1} / \mathrm{Na}_{2} \mathrm{~S}_{2} \mathrm{O}_{5}$. Os resultados indicam que o metabissulfito de sódio é tóxico para $U$. cordatus e este caranguejo pode ser usado para biomonitoramento do impacto ambiental.

Palavras-chave: carcinicultura, impacto ambiental, metabissulfito, concentração letal, espécie neotropical.

\section{REFERENCES}

ANGER K. 1995. The conquest of freshwater and land by marine crabs: adaptations in life-history patterns and larval bioenergetics. J Exp Mar Biol Ecol 193: 119-145.

Aragão JS, Castro BC AND Costa-Lotufo LV. 2008. Toxicidade do metabissulfíto de sódio em Mysidopsis juniae. Arq Cienc Mar 41: 24-29.

BADARÓ-Pedroso C, REYNIER MV AND PRÓSPERI VA. 2002. Testes de toxicidade aguda em misidáceos - ênfase nas espécies Mysidopsis juniae e Mysidium gracile (Crustacea: Mysidacea), p. 123-139. In: Nascimento IA, Sousa ECPM and Nipper M (Eds), Métodos de ecotoxicologia marinha. Aplicações no Brasil. Artes Gráficas e Indústria Ltda, 262 p.

BOYD CE. 1989. Water Quality Management and Aeration in Shrimp Farming. Fisheries and Allied Aquaculture Departamente: Series $N^{\circ}$ 2. Alabama Agricultural Experiment Station, Alabama, $482 \mathrm{p}$.

CONAMA - Conselho Nacional de Meio Ambiente. 1986. Publicado no Diário Oficial da União de 30/07/1986. Disponível em: < http://www.mma.gov.br/port/conama/ res/res 2086.html>. Acesso em: 21 de fev. de 2009.

Diele K, Koch V and Saint-Paul U. 2005. Population structure, catch composition and CPUE of the artisanally harvested mangrove crab Ucides cordatus: Indications for overfishing? Aquat Liv Res 18: 169-178.

FMAIA-IND.COM.LTDA . 2010. Ficha de segurança de acordo com a norma NBR 14725:2009 Fispq No. SA-39. Disponível em: < http: www.fmaia.com.br. 27 de jul. de 2012.

GALli BSO, FuJimoto RY AND ABRUnhosA FA. 2012. Acute toxicity of sodium metabisulphite in larvae and postLarvae of the land crab, Cardisoma guanhumi. Bull Environ Contam Toxicol 89(2): 274-280.

GLASER M. 1999. Sustainability in the management of mangrove crabs (Ucides cordatus) in coastal Pará, Caeté estuary, North Brazil. Proceedings of the Annual Conference of the Development Studies Association (DSA) University of Bath, UK, 13 p.

Glaser M AND Diele K. 2004. Asymmetric outcomes: assessing central aspects of the biological, economic and social sustainability of a mangrove crab fishery, Ucides cordatus (Ocypodidae), in North Brazil. Ecol Econ 49: 361-373. 
HAMILTON MA, RUSSO RC AND THURSTON V. 1977. Trimmed Spearman-Karber method for estimating medial lethal concentrations in toxicity bioassay. Environ Scien Techonol 7: 714-719.

IBAMA. 1987. Instituto Brasileiro do Meio Ambiente e dos Recursos Naturais Renováveis. Avaliação da toxicidade aguda para microcrustáceos. In: Manual de testes para avaliação de ecotoxicidade de agentes químicos, Brasília, $128 \mathrm{p}$.

Laurila E, KerVinen R And AhVenainen R. 1998. The inhibition of enzymatic browning in minimally processed vegetables and fruits. Agbiotech News and Information 9: 53-66.

LOMBARDI JV. 2004. Fundamentos de toxicologia Aquática. In: Sanidade de organismos Aquáticos. RANZANI PMJT, TAKEMOTO RM AND LIZAMA MAP (Eds), Varela, São Paulo, p. 263-272.

MACINTOSH DJ AND PHILLIPS MJ. 1992. Environmental considerations in shrimp farming. Infofish Int 6: 38-42.

Miri R AND ChOUIKHI A. 2005. Ecotoxicological marine impacts from seawater desalination plants. Desalination 182: 403-410.

NASCIMENTO SA. 1993. Biologia do caranguejo-uçá (Ucides cordatus). Administração estadual do meio ambiente (ADEMA), Aracajú, SE, 48 p.
NG PKL, GUINOT D AND DAVIE PJF. 2008. Systema Brachyurorum: part I: an annotated checklist of extant brachyuran crabs of the world. The Raffles Bull Zool 17: 1-286.

OSTRENSKY A, BorghetTI JR AND SOTO D. 2008. Aquicultura no Brasil: o desafio é crescer. Brasília, 276 p.

RAND GM AND PETROCELLI SR. 1985. Fundamentals of aquatic toxicology, Washington, $665 \mathrm{p}$.

SANTOS MCF. 2002. Drinking and osmoregulation in the mangrove crab Ucides cordatus following exposure to benzene. Comp Biochem Physiol A 133: 29-42.

SILVA RR. 1988. Considerações sobre o uso e o mal uso de sais de sulfito em crustáceos. In: Seminário sobre Controle de Qualidade na Indústria de Pescado, Santos. Anais. Santos: Loyola, p. 244-259.

VALENÇA AR. 2003. Tratamento de efluentes. Panorama Aquac 13: 73-74.

VINATEA LA. 1999. Aquicultura e desenvolvimento sustentável. Subsídios para a formulação de políticas de desenvolvimento da aquicultura brasileira. Ed. Florianópolis: Editora da UFSC, $310 \mathrm{p}$. 